\title{
Evaluation of Hydraulic Performance On Lower Areb Small Scale Irrigation Scheme Amhara, Ethiopia
}

Gashaw Sintayehu Angualie ( $\sigma$ gashawsintayehu774@gmail.com )

woldia university

Alemshet Belayneh

Woldia University

Kibru Gedam Berhanu

Gonder University

Tirunesh Muluken Munye

Mekdela Amba University

Kefale Ejigu

woldia university

Chalachew Alemu

woldia University

Dawit Munye Tamirat

Debre Tabor University

\section{Research Article}

Keywords: Lower Areb irrigation scheme, Hydraulic performance, physical sustainability, maintenance indicators

Posted Date: October 29th, 2021

DOI: https://doi.org/10.21203/rs.3.rs-985549/v1

License: (c) (1) This work is licensed under a Creative Commons Attribution 4.0 International License.

Read Full License 
3 Gashaw Sintayehu $^{1 *}$, Alemshet Belayneh ${ }^{2}$, Kibrit Gedam ${ }^{3}$, Tirunesh Muluken ${ }^{4}$, Kefale

4 Munyeh $^{5}$ Chalachew Mulat ${ }^{6}$

$5 \quad{ }^{1}$ Department of Water resources and Irrigation Engineering, Institute of Technology,

6 Woldia University, P.O.Box 400 Woldia, Ethiopia,

7 gashawsintayehu774@gmail.com;Tel.:+251-9-18-31-53-23

$8{ }^{2}$ Department of Water resources and Irrigation Engineering, Institute of Technology,

\section{Evaluation of Hydraulic performance on Lower Areb small scale irrigation scheme} Amhara, Ethiopia
WoldiaUniversity, P.O.Box 400 Woldia, Ethiopia, E-Mail: alembe29@gmail.com Tel.:+251-9-11-58-79-87

${ }^{3}$ Department of Hydraulic and Water Resources Engineering, Institute of Technology, University of Gondar, P.O.Box 196 Gondar, Ethiopia, E-Mail:

meftihewgedam6477@gmail.com;Tel.:+251-9-36-58-48-45

${ }^{4}$ Department of Agricultural Economics, Collage of Agriculture, Mekdela Amba University,Ginba,Ethiopia,E_Mail:muluken.tirunesh@gmail.com:Tel:+251_9_37_34_14 $-26$

${ }^{5}$ Department of Water resources and Irrigation Engineering, Institute of Technology, Woldia University, P.O.Box 400 Woldia, Ethiopia, kefalemunye1921@gmail.com,Tel: +251_18_60_09_47

${ }^{6}$ Department of Water resources and Irrigation Engineering, Institute of Technology, Woldia University, P.O.Box 400 , Woldia, Ethiopia, mulatchalachew@gmail.com,Tel: +251_18_37_26_32

\section{ABSTRACT}

This study was conducted in the Lower Areb small-scale irrigation scheme for one crop season from March to May 2018 to evaluate the hydraulic performance of the scheme by estimating the hydraulic performance indicators, physical performance indicators, and maintenance performance indicators. The primary data including water flow rate, soil physical properties, and water infiltration were collected. The secondary data collected were climatic, crop data, and data from different reports and design documents including the irrigation water users' interviews. The hydraulic performance of the irrigation scheme 
was evaluated by estimating adequacy, efficiency, dependability, and equity indicators at nine selected offtakes; three each at the head, middle, and tail reaches of the scheme. The physical performance and maintenance indicators were determined using the irrigation ratio, the sustainability of the irrigated area, the effectiveness of infrastructure, and the water surface elevation ratio. The data were analyzed by using CROPWAT 8.0, ARC GIS 10.1 software, and Microsoft Excel 2013. The overall average values of adequacy, efficiency, dependability, and equity were found to be $0.89 .0 .91,0.096$ and 0.07 respectively. Therefore, dependability, equity, and efficiency were under good condition and adequacy was under fair condition. The irrigation ratio and sustainability of irrigated areas were $54 \%$ and $123 \%$ respectively. The effectiveness of infrastructure and water surface elevation ratios were $73.33 \%$ and $94 \%$ respectively.

Keywords: Lower Areb irrigation scheme, Hydraulic performance, physical sustainability, and maintenance indicators.

\section{ACRONYMS AND ABBREVIATIONS}

Actual Water Surface Elevation

Crop Water Requirement Estimation Model Window 8

Spatial Coefficient of Variation

Temporal Coefficient of Variation

Crop Water Requirement

Designed Water Surface Elevation

Deviation of Water Surface Elevation

Effectiveness of Infrastructure

Crop Evapotranspiration

Reference Crop Evapotranspiration

Irrigated Ratio

Meter Above Sea Level

Adequacy

Dependability

Equity

Efficiency

Actual Delivered Discharge

Actual Required Discharge 
SIA

WSER

Sustainable Irrigated Area

Water Surface Elevation Ratio

\section{INTRODUCTION}

Ethiopia has abundant rainfall and water resources, but the agricultural system does not use fully the technologies of water management and irrigation (Tariku, E \& Ayana, M, 2017). The majority of the population in Ethiopia depends on rain-fed agricultural production for its livelihood. However, the total crop production is not sufficient to fulfill the food requirements of the country. One of the best alternatives to be considered for reliable and sustainable food security development is expanding irrigation development at various scales (Lambisso, 2008). Irrigation development is an important tool to stimulate economic growth and rural development, and it is considered a cornerstone of food security and poverty reduction in Ethiopia. Increased availability of irrigation and less dependency on rain-fed agriculture taken as a means to increase food production and self-sufficiency of the rapidly increasing population in the country (Rust and Snellen, 1993; Awulachew et al., 2005).

In Ethiopia, there is a large irrigation potential (5.3 million ha), but the area developed under irrigation is less than its potential (Dejen et al., 2015). Even, the developed irrigation schemes do not perform well as planned and expected because of several interrelated factors. The hydraulic performance of the irrigation scheme is one of the crucial issues, which hinders the irrigation development in Ethiopia attributed to low performances (Awulachew and Ayana, 2011). Among the factors which pose the low performance of irrigation schemes are poor design, inadequate irrigation scheduling, inadequate operation plan, waterlogging, inadequate water control facilities, lack of adequate maintenance, and other management gaps related to the distribution of irrigation water between beneficiaries (Awulachew, 2010; Dejen et al., 2015; 2016; Dejen et al., 2015; Firew, et.al, 2017; Woodroofe, 1993). To alleviate these problems and increase food production for sustainable food security of increased population growth, the irrigation scheme should be achieved by efficient and effective irrigation management (Tebebal and Ayana, 2015; Tariku \& Ayana, 2017). Therefore, giving more consideration to the existing irrigation schemes and evaluating their performance is a crucial issue to minimize losses of water and improve the irrigation water use efficiency. 
Performance assessment is used to identify the present status of the performance of the scheme using different indicators. These indicators evaluate the spatial and temporal distribution of the required and delivered water for the given irrigation scheme (Tebebal, 2015) The in-situ measurement can provide a quantitative assessment of overall system performance. Therefore, this study was intended to evaluate the hydraulic performance of the irrigation scheme with irrigation service at Lower Areb small-scale irrigation scheme, Ethiopia.

\section{MATERIALS AND METHODS}

\subsection{Location of the Study Area}

Lower Areb small-scale irrigation scheme is located in between North and South Achefer district of West Gojjam Zone, Ethiopia. The Lower Areb River is supplied water from the Upstream of Yismala passing through Gilgel Abbay River.

Geographically the project area is located at $11^{0} 30^{\prime} 00^{\prime \prime}$ to $11^{0} 36^{\prime} 00^{\prime \prime}$ latitude and $36^{\circ} 48^{\prime}$ $00^{\prime \prime}$ to $37^{0} 00^{\prime} 00^{\prime \prime}$ longitude. The elevation in the watershed varies from 1847 masl on the axis of the headwork to 2200 masl on the upper ridge. The headwork structure is located at an altitude of 1860 masl.

The location map of the Lower Areb small-scale irrigation scheme is shown in Figure 1.

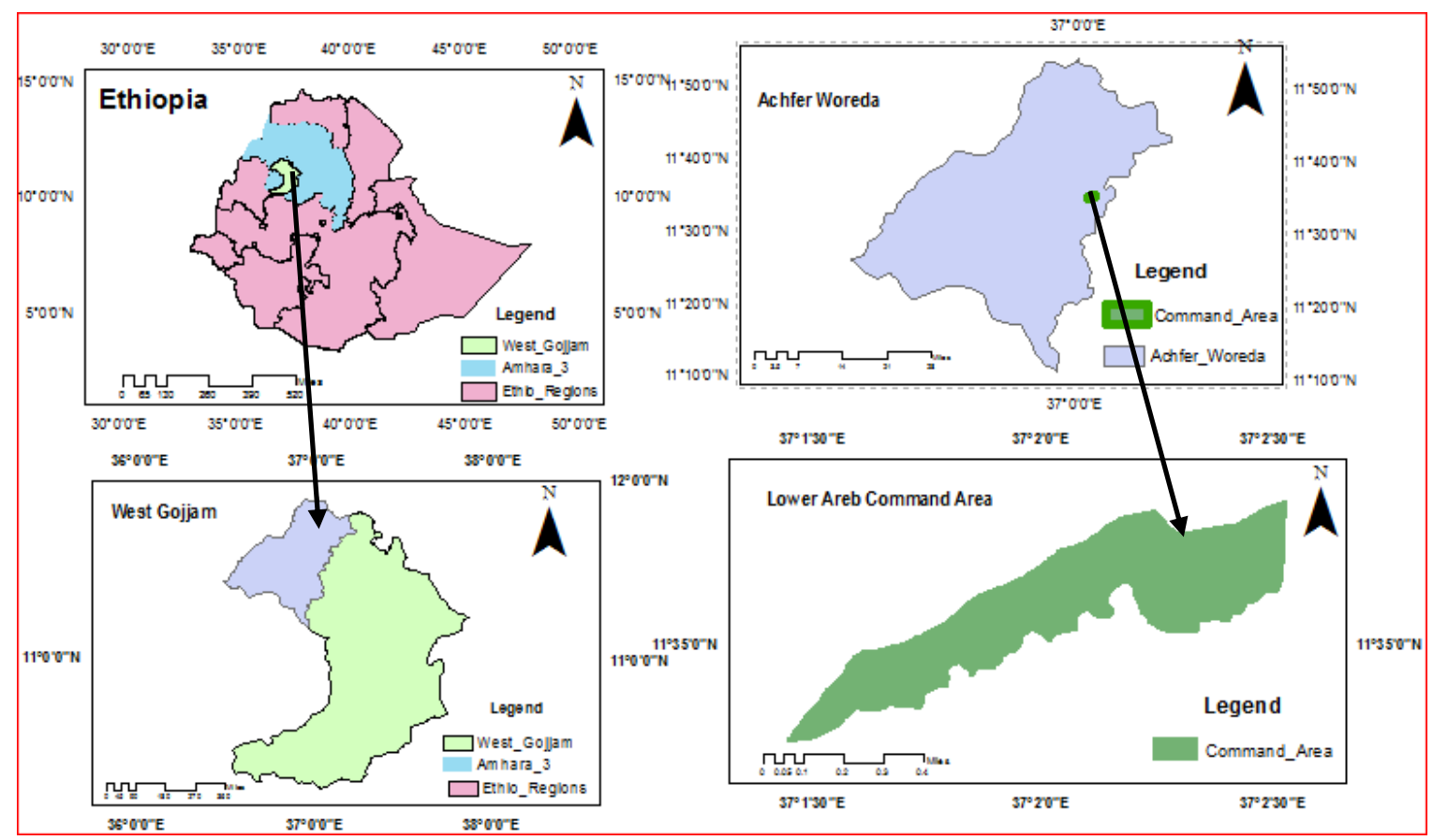

Figure 1: Location map of Lower Areb small scale irrigation scheme 


\subsection{Background of Lower Areb small scale irrigation scheme}

Lower Areb irrigation project was constructed in April 2006 with financial assistance from World Bank. The project has been given a four-year operational service period. The irrigation system encompasses one intake outlet at the left of the headwork and the canal network with 1 main canal and 12 tertiary canals. The intake outlet was controlled by the under sluice gate and the trash rack for guaranteeing the normal diversion and to remove sediment entering and flood to the main canal to keep the safe operation of the system. The main canal was a lined rectangular canal that starts from the intake outlet on the left side of the headwork conveys water for a length of $2.594 \mathrm{~km}$. The tertiary canals were an earthen trapezoidal canal that offtakes water from the main canal and divides it among field canals. The water distribution was rotational for tertiary canals. The layout of the Lower Areb irrigation scheme is shown in Figure 2.

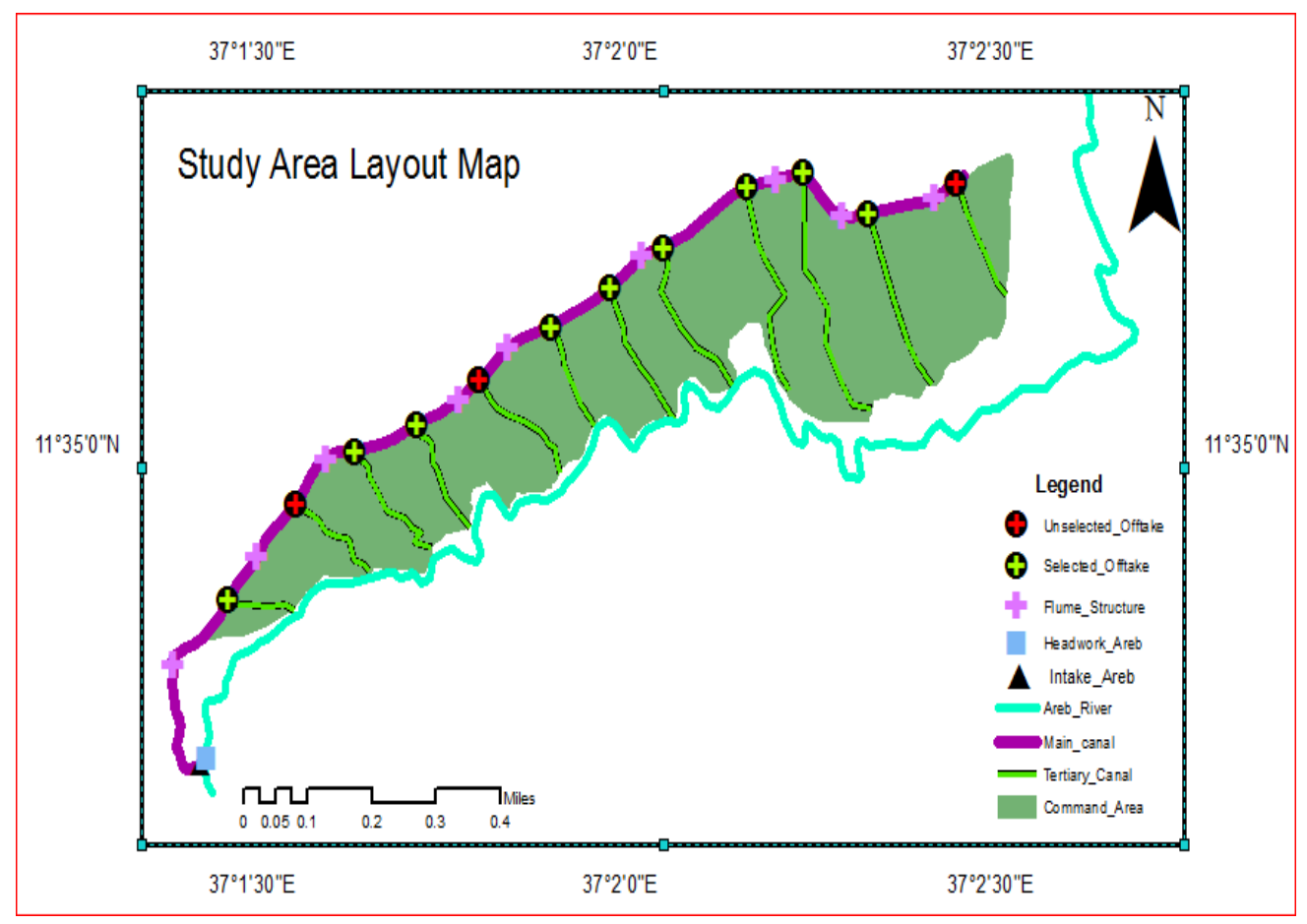

Figure 2: Layout of Lower Areb irrigation scheme

\subsubsection{Soil}

The soils of the project command area according to the design document were divided into two major soil types, Vertisoils, and luvisiols. Vertisols are deep and heavy clay soils that swell and shrink. Luvisols are deep reddish clay soil. Soils of the plains in the Lower Areb area were deep and possess good drainage characteristics. Soil texture in the study area was clay and clay loam with clay dominating. 


\subsubsection{Climate}

The project area is characterized by "Woyenadega" agroecology based on the elevation of the area. The rainfall pattern of the project area is unimodal type in which one main rainy season occurs during July to August. The average monthly rainfall in July and August is $360.8 \mathrm{~mm}$ and $378.3 \mathrm{~mm}$ respectively. The mean annual rainfall of the area is $1630.2 \mathrm{~mm}$. The prevailing temperature considerably influences the selection of crops and their growing periods. The mean maximum and minimum annual temperature are $25^{\circ} \mathrm{C}$ in April and $9.3^{\circ} \mathrm{C}$ in January respectively. The mean monthly and sunshine hour duration of the project area varies between 4.2 hours per day to 8.9 hours per day with an annual average value equal to 7.1 hours per day. The mean monthly relative humidity in the project area varies from the lowest $44 \%$ in February to the highest $78.1 \%$ in August with a mean annual value equal to $61.8 \%$. The mean monthly wind speed varies from $52 \mathrm{~km}$ per day in November to 93 $\mathrm{km} /$ day in May with the mean annual value equal to $75 \mathrm{~km} /$ day.

\subsubsection{Crop}

The major irrigated crops grown in the Lower Areb irrigation scheme are cereal and vegetable crops. The cereal crops are maize, teff, sorghum, barley, and wheat. The vegetables are potato, onion, tomato, and cabbage. Crops grown in the area vary from season to season. The crops grown during the present study period were potato, maize, onion, wheat, and barley. The dominant crop grown in the command area of this irrigation scheme was the potato.

\subsection{Sampling Technique}

Conducting in-situ measurements in all canal branches and for each offtake was a difficult task due to its time-consuming and cost-effectiveness. Therefore, the representative locations for data collection were selected through a stratified sampling technique. The measurements of delivered discharge in the command area were made at 9 selected offtakes out of 12 total offtakes. Three offtakes were selected at each of the upstream, middle, and downstream reaches of the main canal which grow a similar crop in all fields per offtake. In the present study, nine tertiary offtakes which grow similar crops per tertiary offtake were selected since CWR estimation is possible in these offtakes. The layout of the canal and the location of selected offtakes for discharge measurement are shown in figure 2. 


\subsection{Methodology and Data Collection}

This study was carried out for one irrigation season, from March to May 2018. The choice of selecting this period for the study was because there was hardly any rain during the period and almost all field crops were irrigated. Both quantitative and qualitative data were collected from primary and secondary sources. The primary data were collected from direct field measurements, field visits, and laboratory analysis. The secondary data were obtained from the north Achefer district agricultural office, Amhara National Regional Bureau of Water and Irrigation energy, regional meteorological agency, related journals, published and unpublished thesis, and FAO documents.

\subsection{Data Analysis Techniques}

The hydraulic performance was evaluated in the present study by using hydraulic performance indicators, maintenance indicators, and physical sustainability performance indicators. These primary and secondary data were analyzed by using MS excel 2013, CROPWAT 8.0 model, and different relationships as proposed by Molden and Gates (1990).

\subsection{Discharge measurement}

The discharge measurements were one of the reliable data to evaluate scheme performance indicators. The water flow velocity and water flow depth of the offtakes were measured using the current meter and calibrated 3-inch Parshall flume.

\subsubsection{Velocity measurement using current meter}

The current meter is the most widely used device to measure the velocity of water flow. The velocity at the selected points of the reach was measured using SEBA-universal current meter F1 with synthetic propeller, 125mm diameter as shown in Figure 3. It measures the number of revolutions of the propeller per second.

The depth of flow water in the selected point was less than 0.6 meters which is a shallow depth of flow. Therefore, the flow velocity measurements with the current meter were made at $60 \%$ of the depth of water from the water surface (USBR, $2000 ; 2001$ ). The velocity of flow using the current meter at the selected cross-section was determined by counting the number of revolutions within 30 seconds. The measurement was done three times at each location for the same period (30 seconds). The measurement was considered correct and 
the average revolutions considered if the number of revolutions for all three measurements was almost the same.

The velocity of water flow was calculated from the measured values of the current meter propeller revolutions using Equations 2.1 to 2.4.

$$
\begin{aligned}
& V=k * n+\Delta-0.3117 * n+0.0193, \quad \text { if } 0.00<n<1.98 \\
& V=0.3205^{*} n+0.0019, \quad \text { if } 1.98<n<10.27 \\
& V=0.3344 * n-0.1409, \quad \text { if } 10.27<n<15 .
\end{aligned}
$$

Where:

$$
\mathrm{k} \text { is hydraulic pitch of the propeller (m). }
$$

$\Delta$ are characteristics of the current meter $\left(\mathrm{ms}^{-1}\right)$

$\mathrm{n}$ is the number of propeller rotations per second, and

$\mathrm{V}$ is the water flow velocity $\left(\mathrm{ms}^{-1}\right)$.

The canal dimensions were measured using a tape meter. The canal discharge was calculated using Equation 2.6.

$$
\mathrm{Q}=\mathrm{A} * \mathrm{~V}
$$

Where:

$$
\mathrm{Q}=\text { canal discharge }\left(\mathrm{m}^{3} \mathrm{~s}^{-1}\right),
$$

$A=$ flow cross-sectional area $\left(\mathrm{m}^{2}\right)$ and

$$
\mathrm{V}=\text { flow velocity }\left(\mathrm{ms}^{-1}\right)
$$

\subsubsection{Water flow depth measurement using Parshall flume}

Parshall flume is the most commonly used open channel flow measuring device in an irrigation system. It was developed at Colorado State University by Ralph Parshall (Merkley, 2004). It is a critical depth measuring device that is installed in a canal, ditch, or furrow to measure the rate of water flow. The Parshall flume consists of a converging section with a level floor, a throat section with a downward sloping floor, and a diverging section with an upward sloping floor. A Three-inch Parshall flume was installed at the entrance of each field for each of the selected 9 offtakes. The water flow condition in the 
Parshall flume was free flow as shown in Figure 4. The depth-flow relationship for free flow condition in Parshall flume as proposed by Merkley (2004) may be expressed by Equation 2.7.

$$
\mathrm{Q}=\mathrm{KH}{ }^{\mathrm{n}}
$$

where:

$$
\mathrm{Q}=\text { delivered discharge }\left(\mathrm{m}^{3} \mathrm{~s}^{-1}\right)
$$

$\mathrm{H}=$ upstream flow depth in the converging inlet section $(\mathrm{m})$,

$$
\mathrm{K}=\text { free flow coefficient and }
$$

$\mathrm{n}=$ free flow exponent

The values of $\mathrm{k}$ and $\mathrm{n}$ are a function of the dimension of the constriction of the Parshall flume and measurement unit chosen. The value of the constant of $\mathrm{k}$ and $\mathrm{n}$ for three-inch Parshall flumes and metric units were 0.1771 and 1.55 respectively. The validity of the coefficients (free flow coefficient, $\mathrm{K}$ and free flow exponent, $\mathrm{n}$ ) for the study area was examined by measuring the water flow velocity at three tertiary offtake measuring points using the Current meter. The tertiary offtake TO3, TO7, and TO9 were selected to crosscheck the delivered discharge measured using the Parshall flume. The results obtained from the Parshall flume and current meter for the selected control points were almost similar. Therefore, the selected values of the coefficients $K=0.1771$ and $n=1.55$ for the 3 -inch size Parshall flume were correct and further calibration of these coefficients was not mandatory. The minimum and maximum discharge and head range of three-inch Parshall flume are $0.77 \mathrm{l} / \mathrm{s}$ and $32 \mathrm{l} / \mathrm{s}$ and $0.03 \mathrm{~m}$ and $0.33 \mathrm{~m}$ respectively (Merkley, 2004). The discharges may also be determined using Equation 2.7.

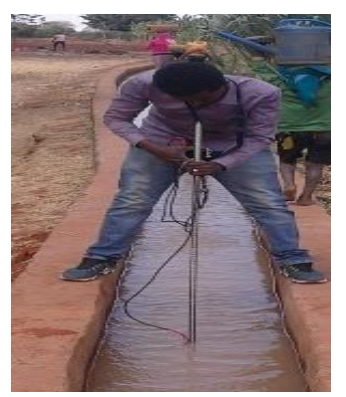

Figure 3: Discharge measurement using Current meter 


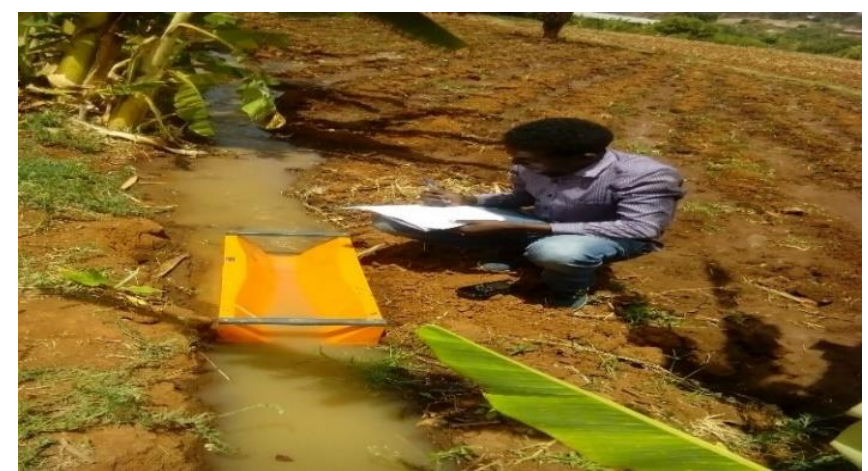

Figure 4: Discharge measurement using Parshall flume

\subsection{Estimation of Crop water requirement}

The CROPWAT version 8.0 program was used to determine the amount of water required for different crops. The crop water requirements, irrigation requirements, and irrigation scheduling were estimated based on soil, climate, infiltration rate, total available moisture, and crop type. Crop characteristics were taken from FAO documents as given in CROPWAT 8.0 program; but, for Onion FAO (1998). The other crop data like planting date, harvesting date, and the length of crop growth period were obtained from the irrigation users. The overall irrigation efficiency for small-scale irrigation was assumed to equal $45 \%$ (Chancellor \& Hide, 1997). The designers of the Lower Areb irrigation scheme also adopted this value of overall irrigation efficiency equal to $45 \%$.

The CROPWAT Model was used to estimate the monthly reference crop evapotranspiration (ETo) and effective rainfall (ER) using 30 years (1987-2017) average climatic data gathered from Regional Meteorological Agency. The climate data were mean monthly maximum and minimum temperature $\left({ }^{\circ} \mathrm{C}\right)$, relative humidity $(\%)$, wind speed $\left(\mathrm{kmd}^{-1}\right)$, sunshine hours (hr.), and mean monthly rainfall $(\mathrm{mm})$. The CROPWAT model uses FAO (1992) Penman-Monteith equation for computing reference crop evapotranspiration. The effective rainfall was computed by using the USDA soil conservation service method (Clarke, 1998). The crop water requirements (CWR) were computed from the crop factor (Kc) and the ETo values for the crop planted. The reference crop evapotranspiration (ETo) was determined by the CROPWAT 8.0 program using climate data of average monthly minimum and maximum temperature $\left({ }^{\circ} \mathrm{C}\right)$, average monthly relative humidity $(\%)$, average monthly sunshine hours, and average monthly wind speed $\left(\mathrm{kmd}^{-1}\right)$. The additional data for determining the water need of crops were soil characteristics of the command area, agronomic data (crop planting date, harvesting date,), crop coefficient (kc), critical 
272 where:

Where:

where:

depletion, and yield response. The effective rainfall (ER) was determined by CROPWAT software using average monthly precipitation.

The allowable soil moisture depletion fractions for each crop at each growing stage were adopted from FAO Irrigation and Drainage paper 24 and 56, and different other research documents. After estimation of the ETo and effective rainfall values for each crop, the crop water requirement and the duty of each crop were determined from the CROPWAT model. The crop water requirement was determined using Equation 2.8. The duty of the crops was determined using Equation 2.9.

$$
\mathrm{ET}_{\mathrm{C}}=\mathrm{K}_{\mathrm{C}} * \mathrm{ET}_{\mathrm{O}}
$$

$$
\mathrm{ET}_{\mathrm{C}}=\text { Crop evapotranspiration (crop water requirement) }
$$

$\mathrm{ET}_{\mathrm{O}}=$ Reference crop evapotranspiration

$$
\mathrm{K}_{\mathrm{C}}=\text { Crop coefficient }
$$

$$
\mathrm{D}=\frac{\mathrm{GIR}}{8.64}
$$

The gross irrigation water requirement (GIR) was estimated using Equation 2.10.

$$
\mathrm{GIR}=\frac{N I R}{E i}
$$

$$
\begin{aligned}
& \mathrm{GIR}=\text { Gross irrigation requirement }(\mathrm{mm}) \\
& \mathrm{NIR}=\text { Net irrigation requirement }(\mathrm{mm}) \\
& \mathrm{Ei}=\text { Overall irrigation efficiency (fraction) }
\end{aligned}
$$

The values of NIR were estimated as under.

$$
\mathrm{NIR}=\mathrm{ETc}-\mathrm{ER}
$$




\begin{tabular}{|l|l|l|l|}
\hline \multicolumn{1}{|c|}{ Indicators } & \multicolumn{1}{|c|}{ Poor } & \multicolumn{1}{c|}{ Fair } & \multicolumn{1}{c|}{ Good } \\
\hline Adequacy indicator $\left(\mathrm{P}_{\mathrm{A}}\right)$ & $<0.80$ & $0.80-0.89$ & $0.90-1.00$ \\
\hline Efficiency indicator $\left(\mathrm{P}_{\mathrm{F}}\right)$ & $<0.70$ & $0.70-0.84$ & $0.85-1.00$ \\
\hline Equity indicator $\left(\mathrm{P}_{\mathrm{E}}\right)$ & $>0.25$ & $0.11-0.25$ & $0.00-0.10$ \\
\hline Dependability $\left(\mathrm{P}_{\mathrm{D}}\right)$ & $>0.20$ & $0.11-0.20$ & $0.00-0.10$ \\
\hline
\end{tabular}

Where:

$\mathrm{ER}=$ effective rainfall, estimated from actual rainfall using CROPWAT software

The required discharge $\left(\mathrm{Q}_{\mathrm{R}}\right)$ for each crop was determined by multiplying the cultivated area of each crop by the duty of the crop as expressed by Equation 2.12.

$$
\mathrm{Q}_{\mathrm{R}}=\mathrm{D} * \mathrm{~A}
$$

where:

$$
\mathrm{Q}_{\mathrm{R}}=\text { the water required for the crop in each offtake structure }\left(1 \mathrm{~s}^{-1}\right)
$$

$$
\mathrm{D}=\text { Duty of each crop }\left(1 \mathrm{~s}^{-1} \mathrm{ha}^{-1}\right)
$$

$$
A=\text { Area covered by each crop irrigated by each offtake (ha). }
$$

\subsection{Hydraulic performance indicators}

The hydraulic performance of the Lower Areb small-scale irrigation scheme was evaluated using performance indicators adequacy (PA), efficiency (PF), dependability (PD), and equity (PE) as proposed by Molden and Gates, (1990).

Molden et al (1990) proposed standards for the hydraulic performance indicators as given in Table 1.

Table 1: Standards for hydraulic performance indicators (Molden et al, 1990)

These indicators were determined using the delivered discharge and required discharge at each of the nine- selected off-takes structures from March to May 2018 as described below. 


\subsubsection{Adequacy}

Adequacy is a measure of the delivery of the required amount of water for optimal plant growth. It relates the actual delivery to the desired amounts of water needed for crop irrigation at delivery points in the system. Adequacy is the ratio of water delivered (QD) to water required $(\mathrm{QR})$ for a single offtake. The adequacy was determined for service area $(\mathrm{R})$ represents the sub-region of the system whose performance is determined and averaged over three months of the study period (T) from March to May 2018 represents the period in which system performance was determined of the entire irrigation system. The adequacy was evaluated as the spatial variation of adequacy levels at the head, middle, and tail offtakes and the temporal variation of adequacy levels throughout the three months using Equation 2.13.

$$
\mathrm{P}_{\mathrm{A}}=\frac{1}{\mathrm{~T}} \sum_{\mathrm{T}}\left(\frac{1}{\mathrm{R}} \sum_{\mathrm{R}} \frac{Q D}{Q R}\right)
$$

where:

$\mathrm{P}_{\mathrm{A}}=$ adequacy indicator over an area $\mathrm{R}$ and Period $\mathrm{T}$,

$\mathrm{Q}_{\mathrm{D}}=$ Actual Amount of Water Delivered at each offtake for a specific period, $\mathrm{Q}_{\mathrm{R}}=$ irrigation water required for crop consumptive use at each offtake for a specific period.

\subsubsection{Efficiency}

Efficiency is the measure of the excess of water delivered in comparison with the requirements. It expresses the ability to conserve water by matching the water deliveries with water requirements and if the system is supplying more than the water requirement, it indicates the non-conservation of the resources. Efficiency is determined as the ratio of required to delivered flows (QR/QD). Efficiency was determined for the head; middle and tail reach off takes using Equation 2.14.

$$
\mathrm{P}_{\mathrm{F}}=\frac{1}{\mathrm{~T}} \sum_{\mathrm{T}}\left(\frac{1}{\mathrm{R}} \sum_{\mathrm{R}}\left(\frac{\mathrm{Q}_{\mathrm{R}}}{\mathrm{Q}_{\mathrm{D}}}\right)\right.
$$

Where:

$$
\mathrm{P}_{\mathrm{F}}=\text { efficiency indicator over an area } \mathrm{R} \text { and period } \mathrm{T} \text {. }
$$




\subsubsection{Dependability}

It is an indicator of the degree of reliability of water delivery. It is the degree of temporal variability in the ratio of the amount delivered to the amount required $\left(\frac{Q D}{Q R}\right)$ over a region. This performance measurement indicates the uniformity of QD/QR over time. An irrigation system that achieves almost steady water distribution is considered to be dependable when the value of PD approaches zero and PD values close to 1.0 indicate serious unreliability of water distribution. This indicator may be estimated using Equation 2.15.

$$
\mathrm{P}_{\mathrm{D}}=\frac{1}{\mathrm{R}} \sum_{\mathrm{R}} C V_{\mathrm{T}}\left(\frac{\mathrm{Q}_{\mathrm{D}}}{\mathrm{Q}_{\mathrm{R}}}\right)
$$

where:

$\mathrm{P}_{\mathrm{D}}=$ dependability indicator over some time $\mathrm{T}$ for a region $\mathrm{R}$, and $\mathrm{CV}_{\mathrm{T}}=$ temporal coefficient of variation of the ratio QD/QR over time $\mathrm{T}$.

The above equation is the general equation of estimating the overall average value of the temporal coefficient of variation of dependability through the time of three months from March to May of the selected 9 offtakes. The value of the temporal coefficient of variation was determined by the ratio of temporal mean and standard deviation. The temporal mean can be determined by the average QD/QR value of a single offtake for three months.

\subsubsection{Equity}

Equity as related to the water delivery system can be defined as the delivery of fair shares of water to the users throughout the system. It is a measure of the spatial uniformity of the water deliveries of the ratio of the amount of water delivered to the amount of water required over the interesting period and shows the fairness of water delivery across the delivery points. The value of Equity close to zero, the greater the degree of equity (special uniformity) of water delivery. The equity was calculated using Equation 2.16.

$$
\mathrm{P}_{\mathrm{E}}=\frac{1}{\mathrm{~T}} \sum_{\mathrm{T}} \mathrm{CV}_{\mathrm{R}}\left(\frac{\mathrm{Q}_{\mathrm{D}}}{\mathrm{Q}_{\mathrm{R}}}\right)
$$

Where:

$$
\mathrm{P}_{\mathrm{E}}=\text { equity indicator over an area } \mathrm{R} \text { for a period of } \mathrm{T} \text {, and }
$$

$$
C V_{R}=\text { spatial coefficient of variation of the ratio } Q D / Q R \text { over a region } R \text {. }
$$


The value of the spatial coefficient of variation was determined by the ratio of the spatial mean over standard deviation. The spatial mean can also be computed by the average ratio of QD and QR values for nine selected offtakes.

\subsection{Physical Sustainability Performance Indicators}

The hydraulic performance of the scheme could also be evaluated through physical sustainability performance indicators. The physical sustainability indicators are related to the changing or losing of irrigated land in the command area due to different reasons. The two relevant physical sustainability performance indicators used in this study were the sustainability of irrigated areas and irrigation ratio as proposed by (Tariku \&Ayana, 2017).

\subsubsection{Sustainability of irrigated area}

SIA is a useful indicator for evaluating the sustainability of irrigated agriculture. The values of SIA were computed by using Equation 2.17.

$$
\text { SIA }=\frac{\text { Currently irrigated Area }}{\text { initially irrigated area }}
$$

The actual irrigated area and initially irrigated area were obtained from district experts, the Water user association, and Development agents. The actual irrigated areas for the irrigation scheme were determined in two ways, the first was by collecting the list of irrigation water users along with their irrigated land holdings compiled by the scheme water user associations and the second was, by using GPS conducted to determine non-irrigated lands, residential areas, and grazing land. The net irrigated land area was then determined as the difference between total command areas and the sum of all non-irrigated land areas within the command.

\subsubsection{Irrigation ratio (IR)}

The irrigation ratio shows the degree of utilization of the available irrigable command area for irrigated agriculture for a particular production period. The value of IR was estimated using Equation 2.18.

$$
\mathrm{IR}=\frac{\text { Currently Irrigated area }}{\text { Currently } \text { irrigable area }}
$$

The irrigable area of the irrigation system was determined by locating GPS to the boundary of the irrigable area. 


\subsection{Maintenance indicators}

Appropriate maintenance enables the keeping of water control and distribution infrastructure in good working condition to maintain the design water level. The hydraulic performance of the scheme could also be evaluated through maintenance performance indicators as recommended by Tebebal and Ayana (2015). The maintenance-based performance indicators for the present study were: effectiveness of infrastructure (EI) and water surface elevation ratio (WSER).

\subsubsection{Effectiveness of infrastructure}

The assessment was focused on the physical structures in the irrigation system components including weir and under sluice except for the drainage system. The existing condition of the main canals was inspected in its operating length alone. The values of EI were estimated using Equation 2.19.

Effectiveness of infrastructure $=\frac{\text { number of functioning structure }}{\text { Total number of structures }}$

\subsubsection{Water surface elevation Ratio (WSER)}

This indicator provides to foresee the scouring and siltation problems in the physical irrigation system. The actual water surface elevation can be computed by using this Equation 2.20. The actual water surface elevation at FSL was measured from the field but the design Water surface elevation was taken from the design report of the Lower Areb irrigation scheme.

$$
\text { WSER }=\frac{(\text { AWSE })}{(\text { DWSE })}
$$

where:

$$
\begin{aligned}
& \text { WSER = water surface elevation ratio in } \%, \\
& \text { AWSE = actual water surface elevation in } m \\
& \text { DWSE = design water surface elevation in } m
\end{aligned}
$$

\section{RESULTS AND DISCUSSIONS}

\subsection{Determination of Required Amount of Water}

The required amount of water for the farmer's field at each of the nine selected offtakes for each of the month's March, April, and May 2018 were estimated using Equation 2.12. The 
estimated values are given in Table 2. The variation of spatial and temporal average values of the required discharge during different months and at different reaches are shown in Figures 5 and 6 . The variation of the required discharge was due to the variation of area coverage and growth stage of the crop. The area coverage of the nine selected offtakes of TO1, TO2, TO3, TO4, TO5, TO6, TO7, TO8, and TO9 were 3, 4, 5, 3, 4, 3.5, 4, 3.5, and 5 ha respectively. The overall mean required discharge of the nine tertiary off-takes during the study period was 3.011/s. It may be observed from Figure 5 that the spatially averaged values of the required amount of water during March, April, and May were 3.241/s, 3.531/s, and 2.271/s, respectively. The required discharge for each offtake was low during March compared to April, because during March the crops were at the initial crop growth stage and the crops need lighter and frequent irrigation. The crops during April were at the midseason and developmental stage the crop water required during April was the higher depth of irrigation water were larger and irrigation was done less frequently. During May crops reached the end of the developmental stage and were late-season stage and thus crop water requirement decreased. Additionally, there were some rains during May and thus the crop irrigation requirements further decreased. It may be observed from table 2 that the reachwise temporal average values of required discharge were 3.011s-1, 2.65 ls-1, and 3.38 ls-1 for the head, middle, and tail reach respectively. The required discharge of the middle reach offtakes was low as compared to head and tail reaches. This discharge variation may be due to the difference in area coverage under each offtake and the variation in crop water requirement at different offtakes. The area coverage at the head, middle and tail reach were $12,10.5$, and 12.5 ha respectively.

\subsection{Determination of Delivered Amount of Water}

The estimated results of the delivered amount of water in the selected nine tertiary offtakes are given in Table 2. The variation of temporal average values for each offtake is shown in Figure 5. The delivered flow varied from 2.10 ls- 1 to 4.52 ls- 1 . The variation of the delivered discharge was based on the area coverage and the availability of water to each offtake or the source of the supply canal to each offtake.

The spatial average values of the delivered amount of flow were 3.56 ls-1, 2.82 1s-1, and 2.591s-1 during March, April, and May respectively. It may be observed from the results during March the delivered discharge was greater than the required discharge because at an initial stage the crop needs less depth of water, but during April the required water was greater than the delivered because in the middle and developmental stage the crop needs 
more depth of water than another stage. During May the delivered discharge was greater than the required discharge because at this month the crop reaches the end of developmental and the start of late-stage at this stage the crop needs less depth of water as compared to the middle and developmental stage. This variation occurred due to the area coverage, crop growth stage, and the availability of water in each offtake, and the diverted water from the canal. The delivered amount of water varied temporally from one location to another location. The temporal average value of delivered flow for the head, middle and tail reaches were $3.64,2.58$, and $2.741 / \mathrm{s}$ respectively.

The temporal average delivered discharge at the head flow was high. This was because due to more area coverage and there was adequate water as compared to middle and tail reach. In the middle and tail delivered discharge was low as compared to the required discharge and the delivered discharge in the head reach. This may be due to the problem of noneffective water usage, the inequitable share of water, and area coverage. The overall mean delivered flow for all of the nine tertiary off-takes during the study period was $2.99 \mathrm{l} / \mathrm{s}$. The overall mean delivered flow was slightly lower than the overall mean of required flow. There may be due to the shortage of water, failure of the intake structure, canal sedimentation problem, and maintenance problem.

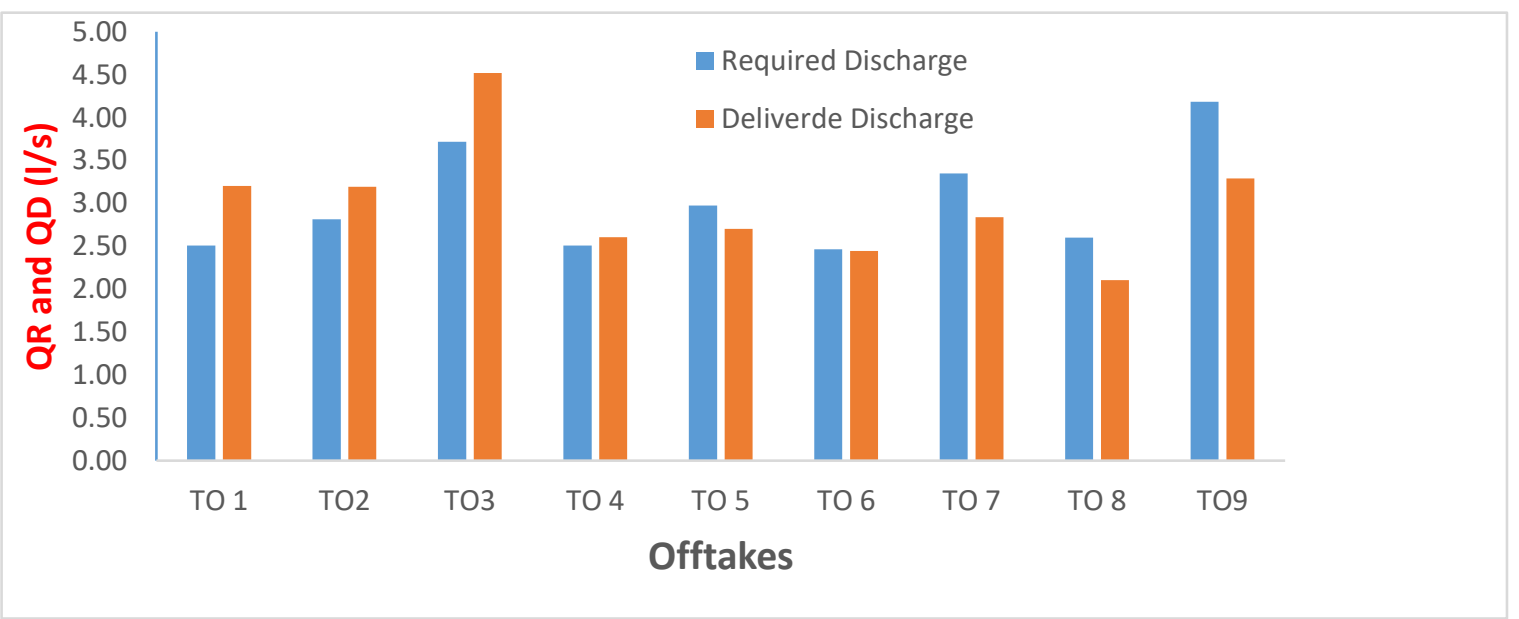

Figure 5: Temporal Average values of required and delivered flow.

Table 2: Estimated Values of Required and Delivered Flow in $1 \mathrm{~s}^{-1}$

Months

Offtakes

Reach

code

March

April

May

QR

QD QR
Mean

Temporal

QR QD 


\begin{tabular}{|c|c|c|c|c|c|c|c|c|c|}
\hline & TO 1 & 2.73 & 4.55 & 3.00 & 2.49 & 1.80 & 2.57 & 2.51 & 3.20 \\
\hline \multirow[t]{4}{*}{ Head } & TO2 & 2.88 & 4.64 & 3.20 & 2.68 & 2.36 & 2.26 & 2.81 & 3.19 \\
\hline & TO3 & 4.05 & 5.80 & 4.30 & 3.88 & 2.80 & 3.89 & 3.72 & 4.52 \\
\hline & mean & 3.22 & 5.00 & 3.50 & 3.01 & 2.32 & 2.90 & 3.01 & 3.64 \\
\hline & TO 4 & 2.73 & 2.52 & 3.00 & 2.43 & 1.80 & 2.87 & 2.51 & 2.60 \\
\hline \multirow[t]{4}{*}{ Middle } & TO5 & 3.24 & 3.09 & 3.44 & 2.89 & 2.24 & 2.14 & 2.97 & 2.70 \\
\hline & TO 6 & 2.52 & 2.18 & 2.80 & 2.28 & 2.07 & 2.87 & 2.46 & 2.44 \\
\hline & mean & 2.83 & 2.59 & 3.08 & 2.53 & 2.04 & 2.63 & 2.65 & 2.58 \\
\hline & TO 7 & 3.64 & 3.21 & 4.00 & 2.89 & 2.40 & 2.41 & 3.35 & 2.84 \\
\hline \multirow[t]{4}{*}{ Tail } & TO8 & 2.84 & 2.33 & 3.01 & 2.28 & 1.96 & 1.705 & 2.60 & 2.10 \\
\hline & TO9 & 4.55 & 3.76 & 5.00 & 3.54 & 3.00 & 2.57 & 4.18 & 3.29 \\
\hline & mean & 3.68 & 3.10 & 4.00 & 2.90 & 2.45 & 2.23 & 3.38 & 2.74 \\
\hline & $\begin{array}{l}\text { Spatial } \\
\text { Mean }\end{array}$ & 3.24 & 3.56 & 3.53 & 2.82 & 2.27 & 2.59 & 3.01 & 2.99 \\
\hline
\end{tabular}

\subsection{Evaluation of Hydraulic Performance Indicators}

\section{$460 \quad$ 3.3.1 Adequacy}

461 The adequacy values were calculated by using Equation 2.13. The graphical variation of 462 the temporal average adequacy values for each offtake is shown in Figure 6. The average 463 values of spatial and temporal adequacy for nine selected tertiary offtakes at the head, 464 middle, and tail reach during the period of one irrigation season from March, April and 465 May are given in Table 3. The temporal average values of adequacy for each of the nine 466 selected offtakes of the study area were varied from 0.80 for tertiary offtake (TO9) to 0.97 467 for Tertiary offtake (TO3). 
468

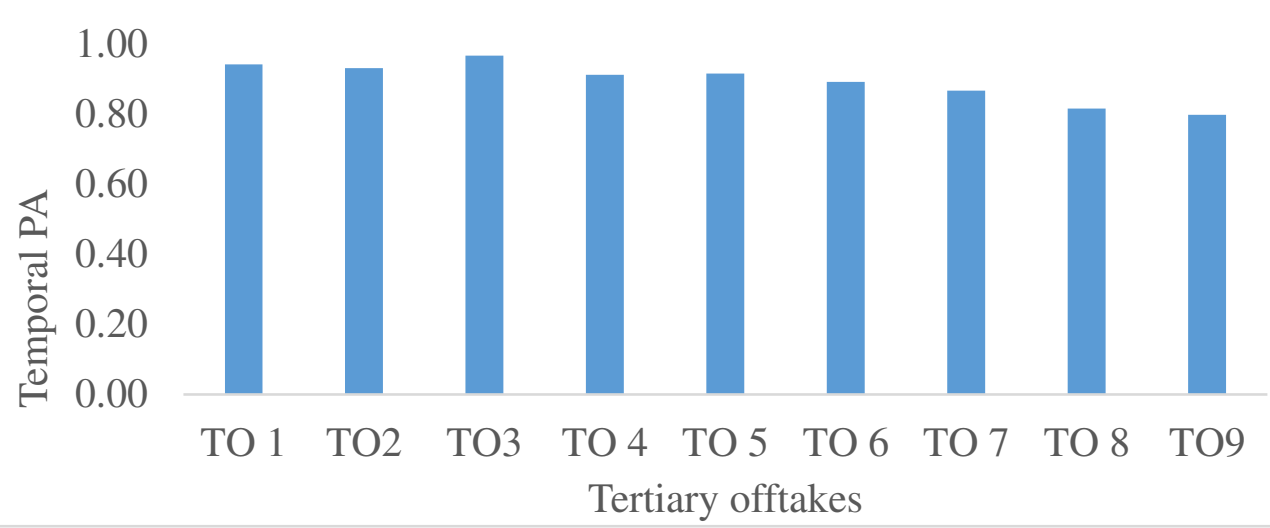

Figure 6: Average temporal adequacy for selected offtakes

It may be observed from Figure 6 that the temporal adequacy values at the tail and head were lower and higher respectively. The adequacy values of tertiary offtakes were 0.89 , 0.87, 0.82, and 0.80 for TO6, TO7, TO8, and TO9 respectively. These offtakes were grouped under fair performance conditions. The values for the other five tertiary offtakes were $0.94,0.93,0.97,0.91$, and 0.92 for TO1, TO2, TO3, TO4, and TO5 respectively. These offtakes were under good performance conditions.

The spatial average values of adequacy were 0.92, 0.80, and 0.96 during March, April, and May respectively. In contrast, the highest spatial adequacy value was found in May and the lowest value was found in April. The amount of water delivered was high during May as compared to March and April. It rained during May reducing irrigation requirements and resulting in higher river flow due to high runoff from upstream catchments areas. The crop was also at the late crop development stage having a lower crop water requirement during May. The water delivered to each offtake during April was lower as the availability of river flow was low during April due to the increase of atmospheric evaporative demand, increased consumption upstream, and absence of rainfall. The crop water requirement during April was also high due to the development crop growth stage. Accordingly, the adequacy during April was lowest. The Adequacy was fair in April and good in March and May as per ranges of water delivery performance standards given by Molden and Gates (1990) in Table 1.

The average temporal values of adequacy at the head, middle and tail reach of the system were $0.95,0.91$, and 0.83 respectively.

It may be observed from table 3 that the average temporal adequacy value was good at the head and middle reach and fair at the tail reach. The overall adequacy of the system was 


\begin{tabular}{llllll}
\hline Reach & Field code & $\begin{array}{l}\text { March } \\
\text { QD/QR }\end{array}$ & $\begin{array}{l}\text { April } \\
\text { QD/QR }\end{array}$ & $\begin{array}{l}\text { May } \\
\text { QD/QR }\end{array}$ & Temporal mean \\
\hline Head & TO 1 & 1.00 & 0.83 & 1.00 & 0.94 \\
& TO2 & 1.00 & 0.84 & 0.96 & 0.93 \\
& TO3 & 1.00 & 0.90 & 1.00 & 0.97 \\
\hline middle & Average & 1.00 & 0.85 & 0.99 & 0.95 \\
& TO 4 & 0.92 & 0.81 & 1.00 & 0.91 \\
& TO 5 & 0.95 & 0.84 & 0.95 & 0.92 \\
& TO 6 & 0.86 & 0.81 & 1.00 & 0.89 \\
\hline Tail & Average & 0.91 & 0.82 & 0.98 & 0.91 \\
& TO 7 & 0.88 & 0.72 & 1.00 & 0.87 \\
& TO 8 & 0.82 & 0.76 & 0.87 & 0.82 \\
& TO9 & 0.83 & 0.71 & 0.86 & 0.80 \\
\hline & Average & 0.84 & 0.73 & 0.91 & 0.83 \\
\hline
\end{tabular}

under the fair category with a value of 0.89 . The result indicated that the scheme was found under satisfactory conditions.

Table 3: Estimated values of adequacy
496

497

498

499

500

501

502

503

504

505

506

507

508

509

\subsubsection{Efficiency}

Efficiency was calculated by using Equation 2.14 for the selected nine tertiary offtake structures. The variation of temporal efficiency at nine selected tertiary offtakes is shown in Figure 7. The temporal efficiency of the selected offtakes varied from 0.77 to 1.00. The irrigation system of the study area was surface irrigation. These values of all reaches were within the acceptable range according to (Molden and Gate, 1990). The maximum value of temporal efficiency at this offtake TO5 was high approaches to one, not exactly one because at this offtake the water users use water effectively and the water requirement of the crop was high. It may be seen from Figure 7 that the values of temporal efficiency were lower at the head offtakes especially at TO1 and TO3 with the respective value of 0.77 and 0.81 , while it was high at TO2 in head reach and for all middle and tail reaches. The offtakes TO1 and TO3 were grouped under fair efficiency level and the other remaining seven offtakes were under good efficiency level. This implies that the irrigation users located at 

received water less efficiently.

512

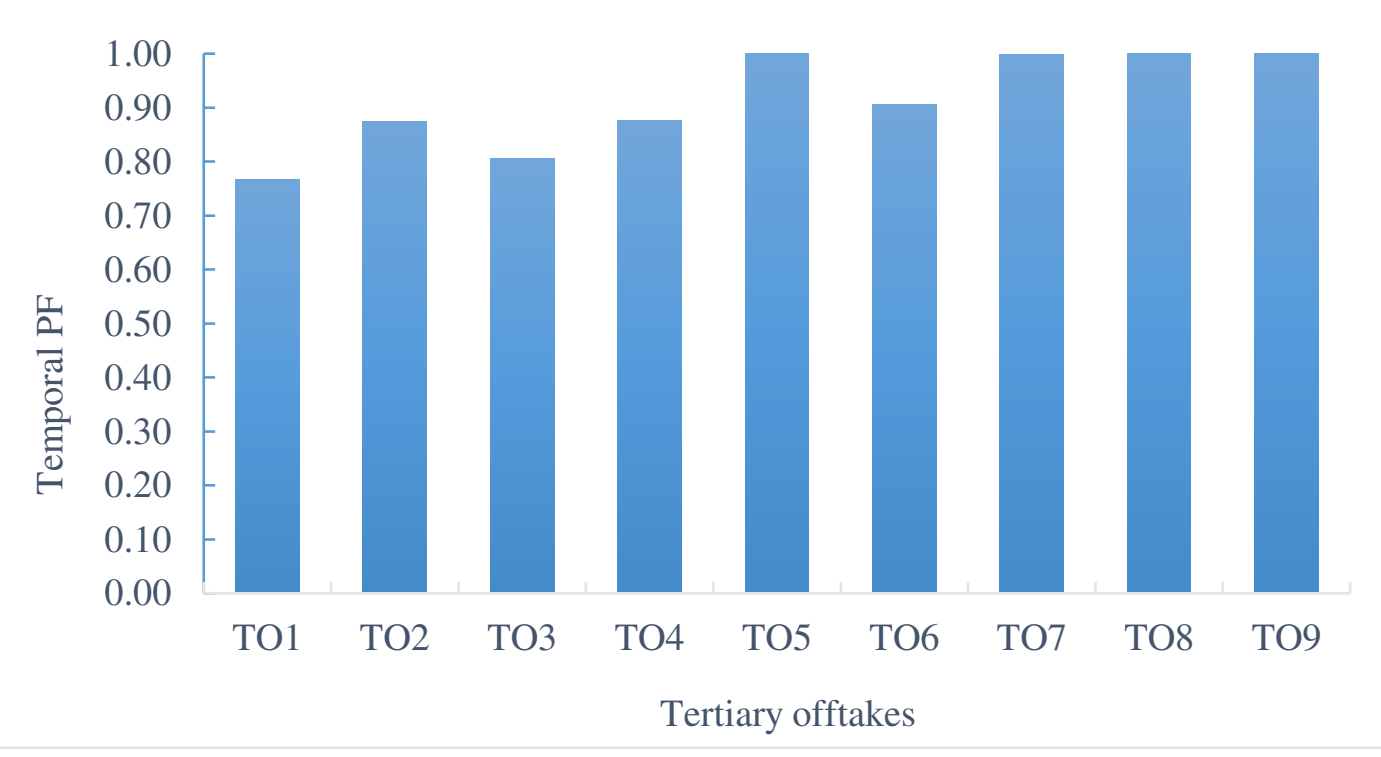

Figure 7: Temporal Average PF

The average spatial efficiency values were $0.88,1.0$, and 0.86 during March, April, and May respectively. The spatial average efficiency value was relatively less during March and May as a result of the delivered amount of water not being used effectively. The delivered amount of water was more than the required water for the crop and the crop water requirement need was less during the period. Generally, during this period there was problem-related to operation and management. Whereas, the spatial efficiency during April was very high, during this month the crop stage was the developmental and mid-stage, at this stage all crops need more water than the delivered amount of water. Therefore, there was high water consumption, and the irrigation users used water efficiently. According to the ranges of water delivery performance standards given by Molden and Gates (1990) in Table 1. The performance level of the spatial mean value of efficiency was categorized under good performance level during March, April, and May months. The average temporal efficiency at the head, middle, and tail were $0.82,0.93$, and 1.00 respectively the efficient water usage at the tail was greater than the head and middle reach. It may be seen from the values of the water at the tail was efficient due to less opportunity to get excess water the water delivered towards the tail end decreased due to unfair water distribution and loss of water in conveyance as compared to head and middle reach. The irrigation users at head reach were in fair performance condition and the users located at middle and tail reaches were grouped under good performance conditions. The overall efficiency of the scheme 
533 was 0.91 . Thus the overall performance condition was categorized under good performance 534 condition.

Table 4: Estimated values of efficiency

\begin{tabular}{lllll}
\hline Field code & March & April & May & Temporal \\
& QR/QD & QR/QD & QR/QD & PF \\
\hline TO 1 & 0.60 & 1.00 & 0.70 & 0.77 \\
TO2 & 0.62 & 1.00 & 1.00 & 0.87 \\
TO3 & 0.70 & 1.00 & 0.72 & 0.81 \\
\hline Average & 0.64 & 1.00 & 0.81 & 0.82 \\
\hline TO 4 & 1.00 & 1.00 & 0.63 & 0.88 \\
TO5 & 1.00 & 1.00 & 1.00 & 1.00 \\
TO 6 & 1.00 & 1.00 & 0.72 & 0.91 \\
\hline Average & 1.00 & 1.00 & 0.78 & 0.93 \\
\hline TO 7 & 1.00 & 1.00 & 0.99 & 1.00 \\
TO8 & 1.00 & 1.00 & 1.00 & 1.00 \\
TO9 & 1.00 & 1.00 & 1.00 & 1.00 \\
\hline Average & 1.00 & 1.00 & 1.00 & 1.00 \\
\hline Spatial PF & 0.88 & 1.00 & 0.86 & 0.91 \\
\hline
\end{tabular}

\subsubsection{Dependability}

537 This dependability was computed as the coefficient of variation of the adequacy values for

538 individual offtakes of the system over three months using Equation 2.15. The adequacy

539 answers the question; does the timing of the water deliveries match the growth needs of the

540 crops and the expectations of the users? (Molden and Gates, 1990) in Table 1. The

541 computed values of dependability are given in Table 5. The temporal coefficient of

542 variation for different offtakes is shown in Figure 8. 


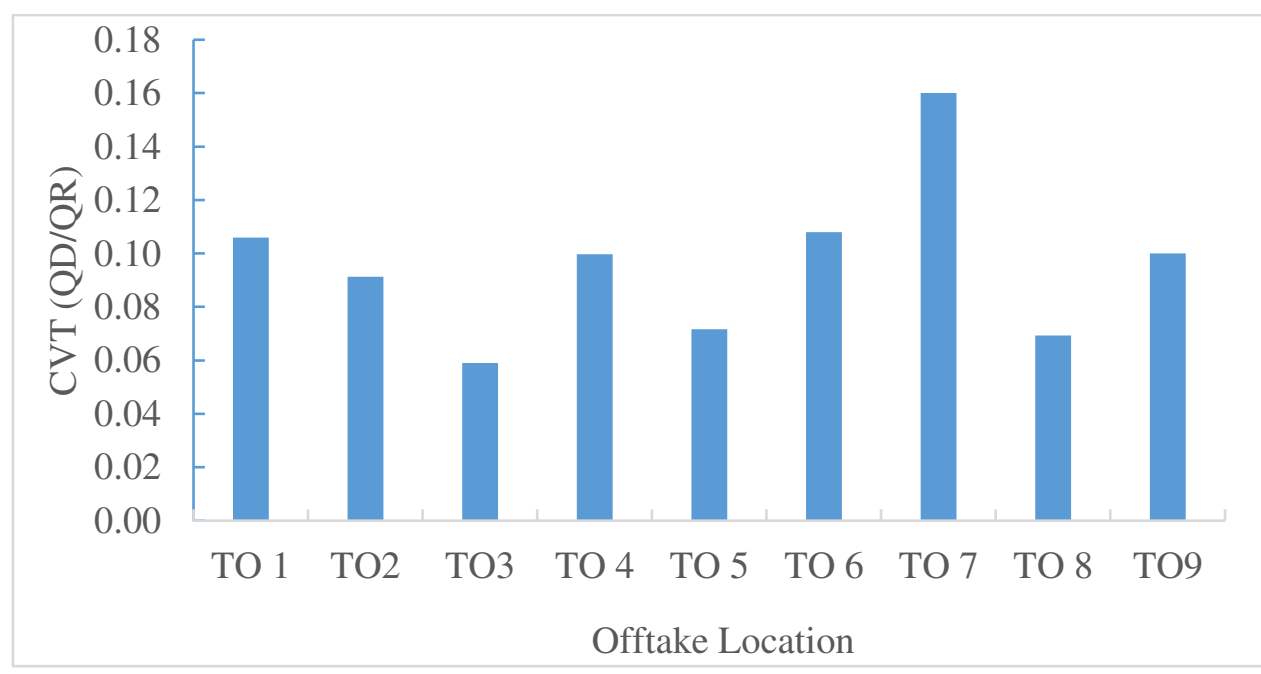

Figure 8: Temporal coefficient of variation (CVT)

It may be observed from Figure 8 that the temporal average coefficient of variation of adequacy varied from 0.06 to 0.16 . The minimum and maximum values were observed for offtake TO3 and TO7 respectively. The delivered amount of water highly varied from one month to another month at offtake TO7, while at offtake TO3 temporal variation of delivered water was low during March, April, and May. The performance level of the Temporal mean value of the coefficient of variation at offtake TO1, TO6, and TO7 was categorized under fair performance level as compared to the ranges of water delivery performance standards given by Molden and Gates (1990) in Table 1. The remaining offtakes were grouped under a good performance level in the reliability of water delivery. Thus the water user associations in tertiary offtakes TO1, TO6, and TO7 did not follow timely and effective water distribution. While the water user association committee followed timely and effective water distribution in tertiary offtake TO2, TO3, TO4, TO5, TO8, and TO9.

The temporal average values of coefficient of variation at the head, middle and tail reach were $0.085,0.093$, and 0.11 respectively. It may be observed from these value the coefficient of variation at tail reaches is as high as compared to head and middle reaches. Thus the farmers at tail reach were not receiving the delivered water timely and in the required amount due to unfair water distribution. While the irrigation users located at head and middle reaches abstracted more water compared to the irrigation users at tail reach. This was due to the weak management of the water committee in distributing irrigation water as per the arranged schedule. The performance levels in the reliability of the irrigation water delivery were good performance at the head and middle reach, while fair performance 
condition at the tail reaches according to the standards proposed by Molden and Gates, (1990) Table 1. The overall temporal coefficient of variation for the selected nine tertiary off-takes was equal to 0.096. This indicates the irrigation scheme was under good performance conditions concerning the reliability of water delivery.

\subsubsection{Equity}

Equity of water distribution was calculated as the coefficient of variation of the adequacy values between different locations throughout three months using Equation 2.16. The estimated results of spatial coefficient of variation (PE) of water distribution over the study period are shown in Table 5. The value of the spatial coefficient of variation varied from 0.059 to 0.079 . The spatial coefficient of variation of equity during March, April, and May was $0.079,0.077$, and 0.059 respectively.

The degree of spatial variation of hydraulic performance for nine selected tertiary offtakes over three months is presented in Figure 9.

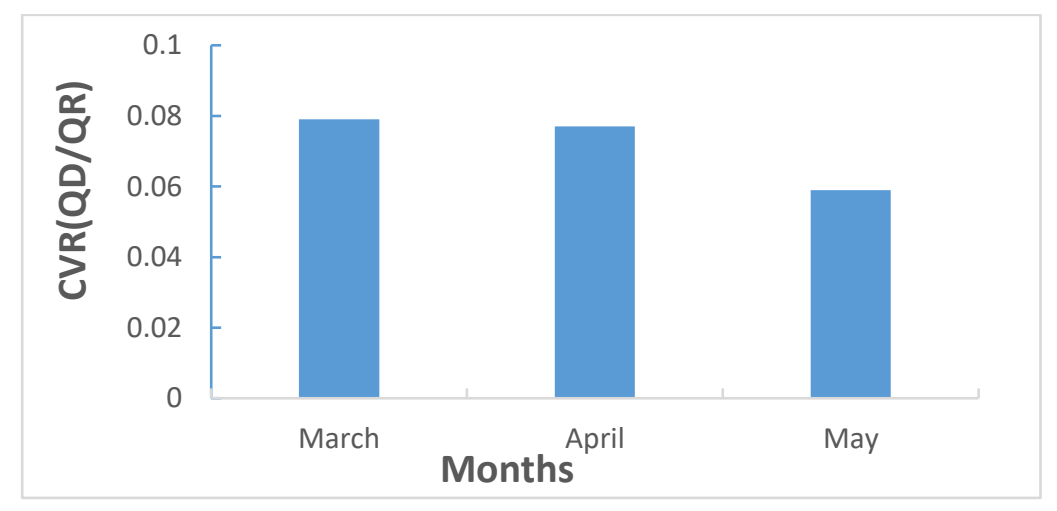

Figure 9: Equity during three months

It may be observed from Figure 9 that the spatial coefficient of variation was higher during March and April due to the unfair share of irrigation water in each offtake structure. While during May spatial coefficient of variation was less in each offtake structure distributed irrigation water. According to standards as proposed by Molden and Gates (1990) Table 1, the equitable share of water in the selected nine tertiary offtakes was good performance conditions during March, April, and May. The overall Average spatial coefficient of variation of the study area was 0.07. Thus, the irrigation scheme was found under good performance conditions in distributing irrigation water in the selected tertiary offtakes during the study period.

Table 5: Estimated values of equity and dependability 


\begin{tabular}{|c|c|c|c|c|c|c|c|}
\hline & & March & April & May & Temporal & St.dev & $\begin{array}{l}\text { CVT, } \\
\text { PD }\end{array}$ \\
\hline & Field code & $\mathrm{QD} / \mathrm{QR}$ & $\mathrm{QD} / \mathrm{QR}$ & $\mathrm{QD} / \mathrm{QR}$ & Mean & & \\
\hline & TO 1 & 1.00 & 0.83 & 1.00 & 0.94 & 0.10 & 0.11 \\
\hline \multirow[t]{3}{*}{ Head } & TO2 & 1.00 & 0.84 & 0.96 & 0.93 & 0.08 & 0.09 \\
\hline & TO3 & 1.00 & 0.90 & 1.00 & 0.97 & 0.06 & 0.06 \\
\hline & TO 4 & 0.92 & 0.81 & 1.00 & 0.91 & 0.10 & 0.10 \\
\hline \multirow[t]{3}{*}{ Middle } & TO 5 & 0.95 & 0.84 & 0.95 & 0.92 & 0.07 & 0.07 \\
\hline & TO 6 & 0.86 & 0.81 & 1.00 & 0.89 & 0.10 & 0.11 \\
\hline & TO 7 & 0.88 & 0.72 & 1.00 & 0.87 & 0.14 & 0.16 \\
\hline \multirow[t]{5}{*}{ Tail } & TO 8 & 0.82 & 0.76 & 0.87 & 0.82 & 0.06 & 0.07 \\
\hline & TO9 & 0.83 & 0.71 & 0.86 & 0.80 & 0.08 & 0.10 \\
\hline & mean & 0.92 & 0.80 & 0.96 & & & 0.10 \\
\hline & St.dev & 0.07 & 0.06 & 0.06 & & & \\
\hline & CVR,PE & 0.079 & 0.077 & 0.059 & 0.072 & & \\
\hline
\end{tabular}

592

593

594

595

596

597

598

599

600

601

602

603

604

605

\subsection{Physical Performance indicators}

\subsubsection{Sustainability of irrigated area}

The sustainability of irrigated area (SIA) of the present study was estimated by using equation 2.17. The estimated value of SIA for two irrigation seasons is given in Table 6 and the graphical variation is shown in Figure 10.

The irrigated area in the 2018 and 2017 irrigation seasons was 43 ha and 50.25 ha, respectively. The estimated value of SIA was $123 \%$ and $144 \%$ in the 2018 and 2017 irrigation seasons respectively. The computed value of sustainable irrigated areas during both of the irrigation seasons 2017 and 2018 was more than 100\%. This indicated that the current irrigated area expanded compared to the initially irrigated area in both of the irrigation seasons. The level of sustainability in 2017 was higher by $21 \%$ as compared to the 2018 irrigation season. This was due to poor maintenance activity of the conveyance structure and failure of some of the flow control structures at the tail reach of the irrigation scheme during 2018. 
606 The sustainability of irrigated areas in the Lower Areb irrigation scheme was higher by 23

$607 \%$ and $44 \%$ in the 2018 and 2017 irrigation seasons respectively. The sustainability of 608 irrigated areas is a long-term process of irrigation system functions working or fails. The 609 sustainability of the scheme over a long period may decrease or increase. Therefore, 610 concrete conclusions may not be drawn based on two-year results of sustainability. Dejen 611 et al. (2012) conducted irrigated area sustainability studies for the Golgota irrigation 612 scheme obtained SIA to be 1.22. Thus the irrigated area at Golgota scheme expanded by 613 about $22 \%$ since commissioning. The results of the present study were similar to the results 614 obtained by Dejen et al (2012) for the Golgota scheme. The contributing factors for the 615 expansion of the irrigated area were dependability of irrigation water supply, farmer's 616 positive attitude to irrigation development, absence of irrigation water fee, and better land 617 productivity.

Table 6: Data related to the area of land at the scheme

\begin{tabular}{ccccccc}
\hline Irrigation & $\begin{array}{c}\text { Current } \\
\text { irrigated }\end{array}$ & Designed & $\begin{array}{c}\text { Initially } \\
\text { irrigated } \\
\text { command } \\
\text { area(ha) }\end{array}$ & $\begin{array}{c}\text { Irrigable } \\
\text { area }\end{array}$ & $\begin{array}{c}\text { sustainable } \\
\text { irrigated }\end{array}$ & $\begin{array}{c}\text { Irrigation } \\
\text { Ratio } \\
(\%)\end{array}$ \\
\hline 2018 & 43 & 65 & 35 & 79 & 123 & 54 \\
\hline 2017 & 50.25 & 65 & 35 & 79 & 144 & 64 \\
\hline
\end{tabular}

619

620

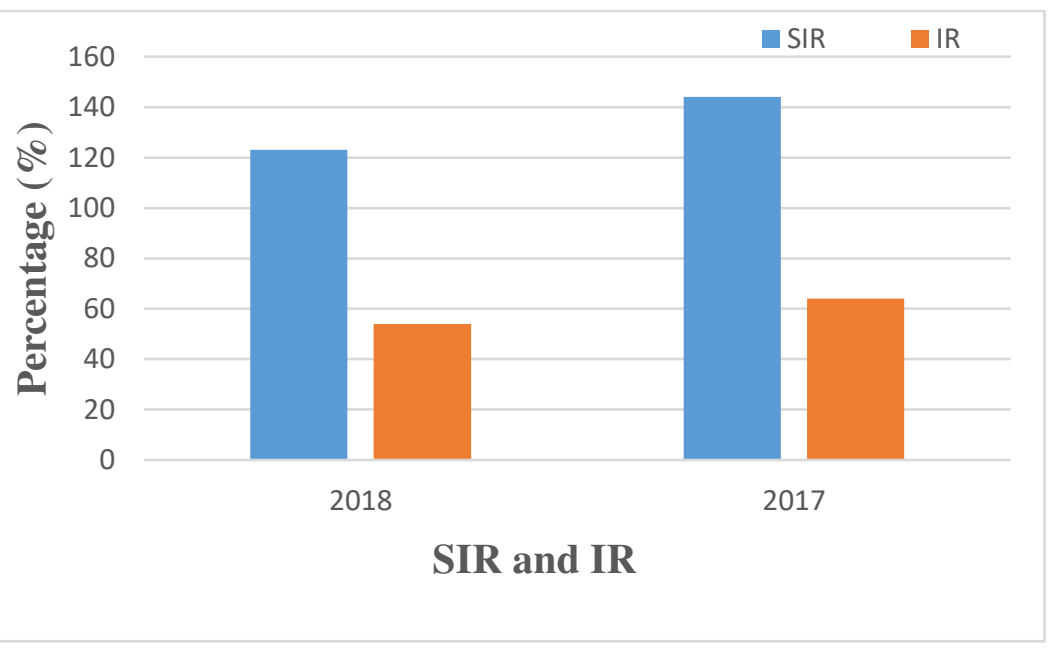

Figure 10: Irrigation ratio and Sustainability of irrigated area 


\subsubsection{Irrigation ratio}

The irrigation Ratio for the present study was estimated using Equation 2.18. The estimated value of IR is given in Table 6 and the graphical variation of irrigation ratio during two irrigation seasons is shown in Figure 10. It may be observed from Table 6, that the irrigated area during 2017 and 2018 was 50.25 ha and 43 ha respectively. Thus the irrigated area decreased by 7.25 ha from 2017 to 2018 . The estimated value of IR was $54 \%$ and $64 \%$ in the 2018 and 2017 irrigation seasons respectively. This means that about $46 \%$ and $36 \%$ of the command irrigable area of the scheme was under irrigation during the 2018 and 2017 irrigation seasons respectively. However, the value of IR in 2017 was higher by $10 \%$ as compared to the 2018 irrigation season. The reasons were similar as for SIA, poor maintenance activity of the conveyance structure and failure of some of the flow control structures at the tail reach of the irrigation scheme. It may be seen from the above Table 6 that the difference in the designed command area and the irrigable area was 14 ha. The potential of the irrigable area was greater than the potential of the scheme. The scheme was designed to irrigate only 65 ha of land.

\subsection{Maintenance indicators}

The maintenance indicators of the scheme were assessed in terms of the effectiveness of infrastructure, the physical condition of the canal, and water surface elevation.

\subsubsection{Effectiveness of infrastructure}

The effectiveness of the infrastructure of the irrigation system was computed using Equation 2.19. According to the design document and the field survey, the total number of structures such that weir, sluice gate, intake gate that were installed in the irrigation scheme, and the structures installed on the main and tertiary canals were 60 structures. However, only 44 structures were currently functional. The detail is given in Table 7. Therefore, the value of effectiveness of infrastructures was estimated to be $73.33 \%$. The rest $18.33 \%$ structures were nearly operative and $8.33 \%$ were nearly inoperative. Thus all of the structures in the scheme were not fully functional and were not working efficiently. The result indicated that the maintenance activities of the infrastructure of the scheme were not enough. The reasons were improper design and poor maintenance of the scheme. The infrastructure of the scheme needs maintenance requirements and monitoring physical assets of the irrigation system. Some of the structures located in the irrigation system were 
653 unable to distribute irrigation water fairly and adequately due to design problems and the 654 absence of a controlling gate. Some of the existing physical problems in irrigation 655 structures are shown in Figures $11 \& 12$.

656 Table 7: Effectiveness of irrigation structures in Lower Areb irrigation system

\begin{tabular}{|c|c|c|c|c|c|}
\hline \multirow{3}{*}{ No } & \multirow{3}{*}{$\begin{array}{l}\text { Structure } \\
\text { Name }\end{array}$} & \multirow{3}{*}{$\begin{array}{l}\text { Initially } \\
\text { Installed }\end{array}$} & \multirow{3}{*}{ Operative } & \multirow{3}{*}{$\begin{array}{l}\text { Nearly } \\
\text { operative }\end{array}$} & \multirow{3}{*}{$\begin{array}{l}\text { Nearly } \\
\text { Inoperative }\end{array}$} \\
\hline & & & & & \\
\hline & & & & & \\
\hline 1 & Diversion weir & 1 & 1 & & \\
\hline 2 & Under sluice gate & 1 & & 1 & \\
\hline 3 & intake gate & 1 & & 1 & \\
\hline 4 & offtake gate & 22 & 18 & 2 & 2 \\
\hline 5 & Division box & 18 & 12 & 3 & 3 \\
\hline 6 & Footbridge & 4 & 4 & & \\
\hline 7 & Drop structure & 6 & 5 & 1 & \\
\hline 8 & Culvert & 3 & 2 & 1 & \\
\hline \multirow[t]{4}{*}{9} & washing basin & 4 & 2 & 2 & \\
\hline & total structure & 60 & 44 & 11 & 5 \\
\hline & Effectiveness of & & 73.33 & 18.33 & 8.33 \\
\hline & Infrastructure (\%) & & & & \\
\hline
\end{tabular}

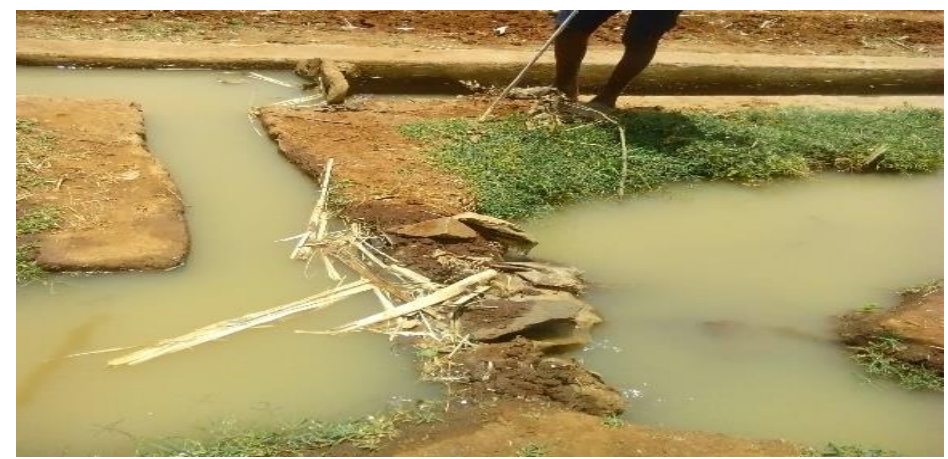

Figure 11: Some of the existing problems in the irrigation structure 
665

666

667

668

669

670

671

672

673

674

675

676

677

678

679

680

681

682

683

684

685

686

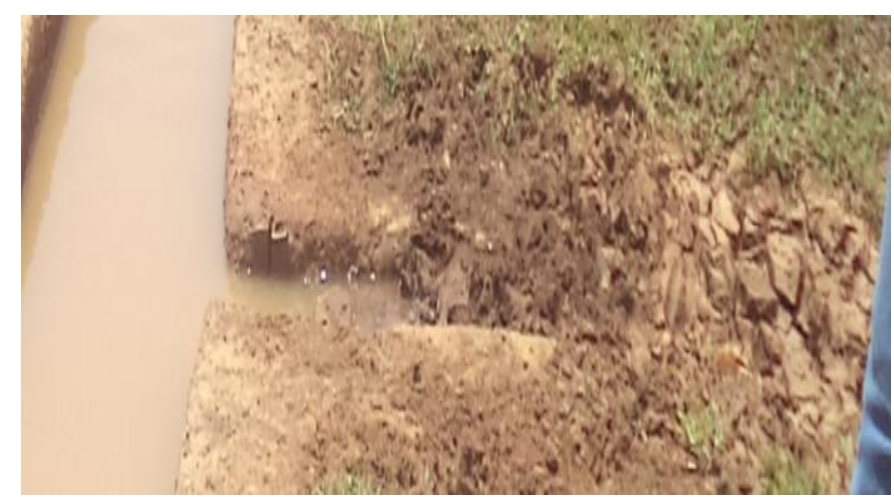

Figure 12: Some of the existing problems in the irrigation structure

Vudhivanich (2008) recommended that the acceptable level of well-functioning infrastructure should not be less than $70 \%$ effective of infrastructure level. The result of the effectiveness of infrastructures for the present study was above the recommended value by Vudhivanich (2008). Thus the overall performance of the infrastructures in the Lower Areb irrigation scheme was in good condition.

\subsubsection{Physical inspection of canal condition}

The physical state of the main canal regarding the canal operating condition was estimated using Equation 2.19. The observed condition of the effectiveness of different structures in different reaches of the main canal is given in Table 8. The conditions of the main canal under different categories in different reach are shown in Figure 13. The estimated values of operative, nearly operative, and nearly inoperative sections of the main canal were 81.53 $\%, 9.83 \%$, and $0.93 \%$ respectively. The reach-wise values of the effectiveness of the main canal were $35.66 \%, 25.83 \%$, and $20.05 \%$ at the head, middle, and tail reach respectively. The overall operational efficiency of the main canal length was $81.53 \%$. Vudhivanich (2008) recommended that the acceptable level of effectiveness for well-functioning infrastructure should not be less than $70 \%$. The estimated value of the effectiveness of the main canal for the present study was more than the recommended value. Therefore, the overall performance of the main canal effectiveness for the Lower Areb irrigation scheme was good. Table 8 physically inspected the effectiveness of infrastructure in different reaches of the main canal in the Lower Areb Irrigation Scheme.

\begin{tabular}{|c|c|c|c|c|c|}
\hline & & & & Nearly & \\
\hline $\begin{array}{l}\text { Structure } \\
\text { Name }\end{array}$ & Reaches & $\begin{array}{l}\text { Operative } \\
\text { in }(\mathrm{m})\end{array}$ & $\begin{array}{l}\text { Nearly } \\
\text { operative(m) }\end{array}$ & $\begin{array}{l}\text { Inoperative } \\
\text { (m) }\end{array}$ & $\begin{array}{l}\text { Effectiveness } \\
(\%)\end{array}$ \\
\hline
\end{tabular}




\begin{tabular}{lccccc}
\hline & head & 925 & 75 & & 35.66 \\
\cline { 2 - 6 } Main canal & middle & 670 & 130 & 24 & 25.83 \\
\cline { 2 - 6 } & tail & 520 & 50 & & 20.05 \\
\hline $\begin{array}{l}\text { Total } \\
\text { length }\end{array}$ & 2594 & 2115 & 255 & 24 & \\
\hline Effectiveness (\%) & 81.53 & 9.83 & 0.93 & \\
\hline
\end{tabular}

Table 8: Effectiveness of infrastructure of the main canal

688

689

690

691

692

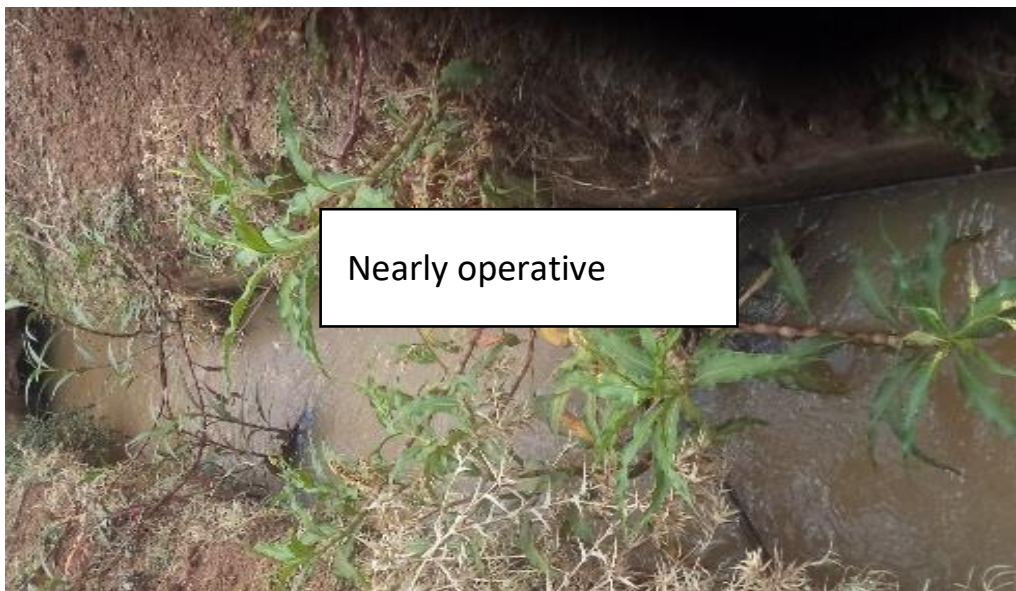

Figure 13 a: Physical conditions of the main canal under different categories

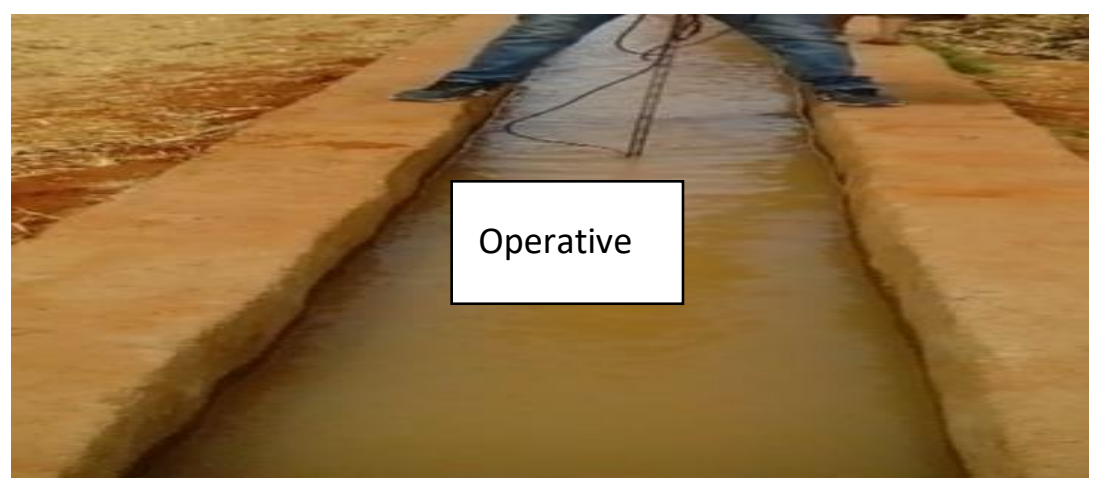

Figure 13 b: Physical conditions of the main canal under different categories 
693

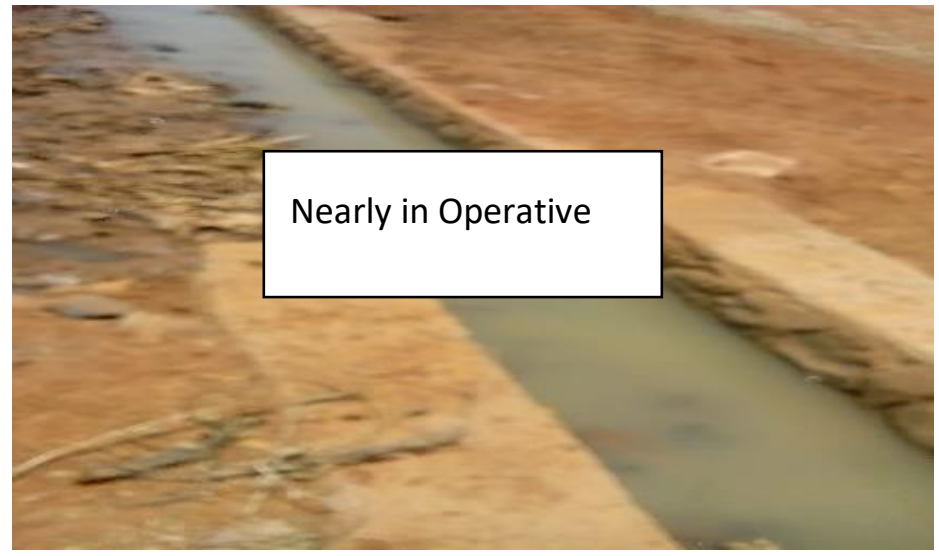

Figure 13 c: Physical conditions of the main canal under different categories

\subsubsection{Water Surface Elevation Ratios (WSER)}

The water surface elevation ratio was estimated by using Equation 2.20. The estimated values of average WSER at the selected monitoring locations in the head, middle, and tail reaches of the main canal are given in Table 9.

Table 9: Average water surface elevation ratio in different reaches of the main canal.

\begin{tabular}{|c|c|c|c|c|c|c|c|c|}
\hline \multicolumn{3}{|c|}{ Head } & \multicolumn{2}{|l|}{ Middle } & \multicolumn{2}{|l|}{ Tail } & \multicolumn{2}{|l|}{ Overall } \\
\hline & $\begin{array}{l}\text { Dev.WSE } \\
\text { (m) }\end{array}$ & WSER & $\begin{array}{l}\text { Dev.WSE } \\
\text { (m) }\end{array}$ & WSER & $\begin{array}{l}\text { Dev.WSE } \\
\text { (m) }\end{array}$ & WSER & $\begin{array}{l}\text { Dev.WSE } \\
\text { (m) }\end{array}$ & WSER \\
\hline Average & 0.017 & 0.93 & 0.015 & 0.94 & 0.005 & 0.96 & 0.01 & 0.94 \\
\hline
\end{tabular}

The design water depths according to the design document of the main canal were $0.25 \mathrm{~m}$ and $0.12 \mathrm{~m}$ from chainage $0-2 \mathrm{~km}$ and $2-2.594 \mathrm{~km}$ respectively. The current average actual water flows depth at full supply level at the head, middle, and tail reaches were $0.234 \mathrm{~m}$, $0.235 \mathrm{~m}$, and $0.115 \mathrm{~m}$ respectively. It may be observed from Table 9 that at the head, middle and tail reaches of the main canal, the average deviation of water surface elevation at full supply level was $0.017 \mathrm{~m}, 0.015 \mathrm{~m}$, and $0.005 \mathrm{~m}$ and WSER were $0.93,0.94$, and 0.96 respectively. The overall average WSER and deviation of WSE were 0.94 and $0.01 \mathrm{~m}$ respectively. Thus the depth of water flow in the main canal reduced on average by $1 \%$ from the designed water flow depth. This reduction in water flow depth was due to different factors such as weed growth, seepage, erosion of canal beds, and evaporation on the main canal. 
In the present study at the 20 measuring points, the positive deviation of WSE was observed at 15 measuring points and negative deviation was observed at 5 measuring points. The positive deviation of the water surface elevation may be due to the factors such as weed growth, seepage, erosion of canal bed, and evaporation on the main canal. The weed growth on the main canal decreased the water surface elevation due to increased water demand by vegetation. Similarly, the evaporation or atmospheric demand, seepage or leakage, and erosion of the canal bed decreased the water surface elevation positively. The negative deviation of water surface elevation may be due to siltation resulting in water overflow if the canal conveyed design discharge. This fluctuation of water surface elevation from the intended value harmed water delivery performance. Therefore, immediate management and engineering measures are needed to take for the main canal for weed removal, sediment clearance, and other preservation works.

\section{Conclusions}

Performance evaluation of irrigation schemes has especially been an important and active field of research during the last few decades. It is used to identify problems and understanding how the system can be effectively implemented to improve the system performance.

The overall average irrigation water required for the selected nine tertiary offtakes for the selected crops such as maize, onion, and potato grown in the command area as compared to irrigation water delivered was more during April but less during March and May. The water delivered by the canal was more than the crop water requirement at head and middle reach but less at tail reach. The temporal and spatial variations of canal water supply in each tertiary offtake were due to weak management of WUAs in irrigation scheduling, cleaning canals sedimentation and weeds, water losses in canals, and damaged water control structures.

The Hydraulic performance of the irrigation scheme was evaluated using adequacy, dependability, efficiency, and equity hydraulic performance indicators. The hydraulic performance of the irrigation scheme as compared to standards proposed by Molden and Gates (1990) was found to be good for dependability, efficiency, and equity, but fair inadequacy. Although the overall hydraulic performance of the irrigation scheme was found to be good, there was some shortage of water during April and an inequitable share of water distribution in the tail reaches. 
The considered maintenance and physical sustainability performance indicators were water surface elevation ratio, the effectiveness of infrastructure, canal operating condition, the sustainability of an irrigated area, and irrigation ratio. Generally, the maintenance performance of the irrigation scheme as per standards proposed by Vudhivanich (2008) was fair. The physical sustainability performance of the irrigation scheme was fair. The irrigation scheme has sustainable irrigated land which can be explained by the expansion of irrigated areas from initially designed.

Generally, the hydraulic performance of the lower Areb irrigation scheme was below the intended objective; this was due to lack of regular maintenance, weak management of WUAs, and stolen flow control gates. Finally, agreements were reached through discussion and persuasion with the irrigation water users and WUAs so that problems could be solved with their contribution and active participation for regular canal maintenance and efficient water distribution and use.

\section{DECLARATIONS}

I, the undersigned declare that this thesis comprises my original work and is not published by any other publishing company. In compliance with internationally accepted practices, I have duly acknowledged and refereed all materials used in this work.

\section{ACKNOWLEDGMENT}

First and above all, I would like to express my sincere gratitude to my respected advisor Professor Pratap Singh for his unreserved supports in giving very crucial and constructive comments starting from the proposal writing until the end of the thesis work. I would like to thank my co-advisor: Mr.Sisay Simachew, for his encouragement, insightful comments, and technical guidance. I would like to thank, Bahirdar Institute of Technology, Faculty of civil and water resources engineering that enabled me to have to access the important instruments for my thesis. Moreover, I would like to thank the Farmers of the Lower Areb irrigation scheme for allowing me to access their farm freely for taking soil samples, flow measurements, and for responding to my questions openly. Finally, I would like to thank my beloved family members and my best friend Tirunesh Muluken for their heart full love, and moral support.

\section{Competing interest}


The authors declare no competing interests.

\section{Funding}

The authors have no funding received for this publication

\section{Data Availability}

The data used to support the findings of this study are available from the corresponding author upon request.

\section{Author contribution}

All authors took part in the research design, data collection process, and manuscript preparation for this publication.

\section{REFERENCE}

Awulachew, S.B. and Ayana, M., (2011). performance of irrigation: An assessment at different scales in Ethiopia. Experimental Agriculture, 47 (S1), 57-69.

Awulachew, S.B., Merrey, D.J., Kamara, A.B., Koppen, B.V., Vries, F.P. \& bBoelee, E. (2005). Experiences and Opportunities for Promoting Small-Scale/Micro Irrigation and Rainwater Harvesting for Food Security in Ethiopia. Working Paper 98(IWMI):P (1-96). Colombo, Sri Lanka. Retrieved from: iwmi@cgiar.org

Chancellor, F. M.,\& Hide, J. M. (1997). Smallholder Irrigation: ways forward. Guidelines for achieving appropriate scheme design, 2.

Clarke, D. (1998). CropWat for Windows: User Guide. Version 8. University of Southampton, UK.

Dejen, Z. A., Schultz, B., \& Hayde, L. (2012). Comparative irrigation performance assessment in community-managed schemes in Ethiopia. African Journal of Agricultural Research, 7(35), 4956-4970.

Dejen, Z. A. (2015). Hydraulic and Operational Performance of Irrigation Schemes given Water Saving and Sustainability: Sugar Estates and Community Managed Schemes in Ethiopia. CRC Press/Balkema.

FAO (Food and Agricultural Organization), (1992). Canals, Irrigation Water Management planning, and management. FAO Training Manual No. 7. 
802

803

804

805

806

807

808

809

810

811

812

813

814

815

816

817

818

819

820

821

822

823

824

825

826

827

828

829

830

831

FAO (Food and Agriculture Organization), (1998). Guideline for computing crop water requirements, FAO, Irrigation and Drainage Paper No. 56, Rome, Italy.

FAO (Food and Agriculture Organization), (2002). Deficit irrigation practices of the United Nations: FAO Water reports No.24. Food and Agriculture Organizations of the United Nations. Rome.

FAO (Food and Agriculture Organization), (2006). Crop Evapotranspiration. FAO Irrigation and Drainage Paper No. 56. Rome.

Lambisso, R. (2008). Assessment of Design Practices and Performance of Small Scale Irrigation Structures in South Region. World Vision Ethiopia, p.(47-57). Retrieved from robelwam2@yahoo.com

Merkley, P. G. (2004). Irrigation conveyance and control: Flow measurement and structural design. Lecture note, Utah State University, BIE 5300/6300, Logan, Utah, USA.p.(18-24)

Molden, D.J. and Gates, T.K. (1990). Performance measures for evaluation of irrigationwater-delivery systems. Journal of irrigation and drainage engineering, 116(6), p.(804-823).

Murray-Rust, D. H. and Snellen, W. B. (1993). Irrigation system performance assessment and diagnosis. Journal of IIMI, ILRI, IHE, International Irrigation Management Institute, Colombo, Sri Lanka 20+148pp.

Tariku \& Ayana. (2017). Hydraulic performance assessment of Tahtay Tsalit small scale irrigation scheme, Tigray, Ethiopia. International Journal of Water Resources and Environmental Engineering, p. (254-263).

Tariku, E. (2017). Comparative Performances Analysis of Two Small-Scale Irrigation Schemes: Case of Tahtay Tsalit and Mychew, Tigray, Ethiopia Masters' thesis. Arba Minch University, Ethiopia. Published.

Tebebal, M. and Ayana, M. (2015). Hydraulic Performance Evaluation of Hare Community Managed Irrigation Scheme, Southern, Ethiopia. International Research Journal of Engineering and Technology(IRJET), 02. Retrieved from www.irjet.net

Tebebal, M. (2015). Evaluation of Hydraulic Performance of Community Managed Irrigation Scheme and Level of User's Satisfaction: A Case Study on Hare 

Irrigation Scheme, SNNPR, Ethiopia. Masters' thesis. Arba Minch University, Ethiopia. Published.

USBR (United State Bureau of Reclamation),(2000 \& 2001). Water Measurement Manual. A Water Resources Technical Publication. United States Bureau of Reclamation (USBR). Washington D.C. Accessed on 20/9/2016, from the web site: Retrieved from http://www.usbr.gov/pmts/hydraulics lab/pubs/WMM/

Vudhivanich, V. (2008). Policies and strategic planning for the Thailand Irrigation Sector Reform Program. FAO Regional Office for Asia and the Pacific, Bangkok.

Woodroofe, R. (1993). Monitoring and evaluation of irrigation projects. Technical manual, manual, Ministry of Water, Irrigation and Energy, Addis Ababa, Ethiopia. 